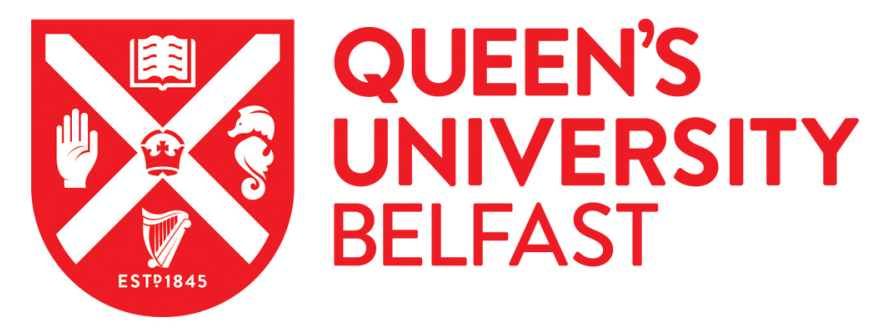

\title{
Nitrogen dynamics and budgets in a winter wheat-maize cropping system in the North China Plain
}

Liu, X. J., Ju, X. T., Zhang, F. S., Pan, J. R., \& Christie, P. (2003). Nitrogen dynamics and budgets in a winter wheat-maize cropping system in the North China Plain. Field Crops Research, 83(2), 111-124.

https://doi.org/10.1016/S0378-4290(03)00068-6

Published in:

Field Crops Research

Queen's University Belfast - Research Portal:

Link to publication record in Queen's University Belfast Research Portal

\section{General rights}

Copyright for the publications made accessible via the Queen's University Belfast Research Portal is retained by the author(s) and / or other copyright owners and it is a condition of accessing these publications that users recognise and abide by the legal requirements associated with these rights.

Take down policy

The Research Portal is Queen's institutional repository that provides access to Queen's research output. Every effort has been made to ensure that content in the Research Portal does not infringe any person's rights, or applicable UK laws. If you discover content in the Research Portal that you believe breaches copyright or violates any law, please contact openaccess@qub.ac.uk. 


\title{
Nitrogen dynamics and budgets in a winter wheat-maize cropping system in the North China Plain
}

\author{
Xuejun Liu ${ }^{\mathrm{a}}$, Xiaotang $\mathrm{Ju}^{\mathrm{a}}$, Fusuo Zhang ${ }^{\mathrm{a}, *}$, Jiarong Pan ${ }^{\mathrm{a}, \mathrm{b}}$, Peter Christie ${ }^{\mathrm{a}, \mathrm{c}}$ \\ ${ }^{a}$ Department of Plant Nutrition, KLPSI-MOE, China Agricultural University, Beijing 100094, PR China \\ ${ }^{\mathrm{b}}$ Institute for Application of Atomic Energy, Chinese Academy of Agricultural Sciences, Beijing 100094, PR China \\ ${ }^{\mathrm{c}}$ Agricultural and Environmental Science Department, Queen's University Belfast, Belfast BT9 5PX, UK
}

Received 17 July 2002; received in revised form 20 February 2003; accepted 26 March 2003

\begin{abstract}
Nitrogen dynamics and budgets in a clay loam soil (Meadow Aqualf) in the North China Plain were investigated in a winter wheat (Triticum aestivum L.) and maize (Zea mays L.) cropping system comparing the effects of four $\mathrm{N}$ rates $(0,120,240$ and $360 \mathrm{~kg} \mathrm{~N}^{-1}$ as urea) applied twice to each crop over 2 years. Ammonium nitrogen $\left(\mathrm{NH}_{4}-\mathrm{N}\right)$ in the soil profile remained at a low and constant level (except in the surface $20 \mathrm{~cm}$ layer) following application of fertilizer N. In contrast, nitrate nitrogen $\left(\mathrm{NO}_{3^{-}}\right.$ $\mathrm{N}$ ) levels were significantly altered by the rate of applied $\mathrm{N}$. A strong tendency of $\mathrm{NO}_{3}-\mathrm{N}$ to move from the surface layer to the lower layers $\left(20-100 \mathrm{~cm}\right.$ ) was observed during the wheat and maize growth seasons in treatments of 240 and $360 \mathrm{~kg} \mathrm{~N} \mathrm{ha}^{-1}$ per crop ( $\mathrm{N} 240$ and $\mathrm{N} 360$ ). The amounts of $\mathrm{NO}_{3}-\mathrm{N}$ accumulated in the soil profile were significantly higher in $\mathrm{N} 240$ and $\mathrm{N} 360$ than those in $\mathrm{N} 0$ and $\mathrm{N} 120$ (treatments receiving 0 and $120 \mathrm{~kg} \mathrm{~N}$ ha $^{-1}$ per crop). After 2 years, soil $\mathrm{NO}_{3}-\mathrm{N}$ levels at $0-300 \mathrm{~cm}$ depth in $\mathrm{N} 120$, N240 and N360 amounted to 336,815 and $1141 \mathrm{~kg} \mathrm{ha}^{-1}$, respectively, with more than half of these amounts distributed in the $100-300 \mathrm{~cm}$ layer. The calculated total $\mathrm{N}$ balance indicates that most fertilizer $\mathrm{N}$ was available as $\mathrm{NO}_{3}-\mathrm{N}$ in the top $300 \mathrm{~cm}$ of the soil profile using traditional fertilization and irrigation practices. Over the subsequent 2 years, $\mathrm{N}$ losses were calculated to be relatively low in $\mathrm{N} 120$ but significantly higher in $\mathrm{N} 240$ and $\mathrm{N} 360$. Measured gaseous $\mathrm{N}$ losses showed that $\mathrm{NH}_{3}$ volatilization and denitrification comprised only a small fraction of total $\mathrm{N}$ losses during the 2-year rotation, while $\mathrm{NO}_{3}-\mathrm{N}$ leaching from the top $100 \mathrm{~cm}$ of the soil profile accounted for most $\mathrm{N}$ losses across all $\mathrm{N}$ rates and experimental years. The $\mathrm{N}$ budget showed that accumulation and/or leaching of $\mathrm{NO}_{3}-\mathrm{N}$ below $100 \mathrm{~cm}$ depth (beyond the reach of most roots) was the main pathway for $\mathrm{N}$ losses in the winter wheat-maize cropping system. The recommended $\mathrm{N}$ application rate of $120 \mathrm{~kg} \mathrm{~N} h a^{-1}$ minimized soil $\mathrm{NO}_{3}-\mathrm{N}$ accumulation and leaching losses while maintaining high yields and $\mathrm{N}$ utilization by winter wheat and maize.
\end{abstract}

(C) 2003 Elsevier Science B.V. All rights reserved.

Keywords: Winter wheat-maize cropping; $\mathrm{NO}_{3}-\mathrm{N}$ accumulation and leaching; Gaseous $\mathrm{N}$ losses; $\mathrm{N}$ budgets; China

\section{Introduction}

Nitrogen cycles in intensively managed agricultural ecosystems have received more attention than those in

\footnotetext{
* Corresponding author. Tel.: +86-10-62892499; fax: +86-10-62891016.

E-mail address: zhangfs@cau.edu.cn (F. Zhang).
}

natural ecosystems because fertilizer $\mathrm{N}$ inputs are much higher in the former (Richter and Roelcke, 2000). Increasing fertilizer $N$ inputs to arable land beyond crop needs results in gaseous and leaching loss and/or an enhanced $\mathrm{N}$ input by runoff to surface water (Spalding and Exner, 1993; Xing and Zhu, 2000). As the nation with the largest agricultural production, China consumed 23 million $t$ of fertilizer $\mathrm{N}$ in 2000 
(Anonymous, 2001), accounting for about 28\% of total world N consumption (Fixen and West, 2002). Thus the $\mathrm{N}$ budget and the fate of fertilizer $\mathrm{N}$ in Chinese agricultural systems are becoming important issues and are receiving much attention from both agricultural and environmental scientists (Zhu, 1997; Zheng et al., 2002). The $\mathrm{N}$ budget or balance is often evaluated by comparing various $\mathrm{N}$ inputs and outputs in soil-crop systems by considering changes of soil mineral N (Sogbedji et al., 2000) or not (Sapek, 1997; Zhu, 1997). Research on $\mathrm{N}$ balances that takes into account mineralization and inorganic $\mathrm{N}$ in soils can provide more detailed information on the $\mathrm{N}$ cycles and losses by integrating soil $\mathrm{N}$ process into the total $\mathrm{N}$ budgets (R. Schulz, personal communication). There are limitations to the calculation of $\mathrm{N}$ balances, however, because it is difficult to measure accurately each component of $\mathrm{N}$ budgets in relation to soil processes (Jarvis, 1996; Sogbedji et al., 2000).

Winter wheat-maize double cropping is an important rotation system mainly practiced in an area of $>14$ million ha in the North China Plain (Anonymous, 2001; Zhu et al., 1994) and contributes 48 and 39\% of the total winter wheat and maize production in China, respectively (Liu and $\mathrm{Mu}, 1993$ ). Excessive use of fertilizer $\mathrm{N}$ is very common in the winter wheat-maize cropping system, particularly in regions with high population densities. In the Beijing area, for example, the average $\mathrm{N}$ application rates are $309 \mathrm{~kg} \mathrm{~N} \mathrm{ha}^{-1}$ for winter wheat and $256 \mathrm{~kg} \mathrm{~N}$ ha $^{-1}$ for maize (Zhao et al., 1997). An investigation by Ma (1999) in Shandong province also found average $\mathrm{N}$ application rates of $>500 \mathrm{~kg} \mathrm{~N} \mathrm{ha}^{-1}$ in wheat-maize cropping systems. Clearly, such high $\mathrm{N}$ rates greatly exceed the $\mathrm{N}$ requirements of both crop species at local yield levels and will inevitably lead to large losses of N. Gaseous $\mathrm{N}$ losses, particularly $\mathrm{NH}_{3}$ volatilization, are often considered as the main pathway for fertilizer $\mathrm{N}$ loss on calcareous soils, particularly when urea and ammoniacal fertilizers are applied to the surface of soils (Sommer and Jensen, 1994; Weier, 1994; Zhu and Chen, 2002). However, this loss can be lowered substantially by incorporating the fertilizer $\mathrm{N}$ into the soil or applying just prior to irrigation (Zhang et al., 1989, 1992). In most cases, denitrification is also regarded as an important $\mathrm{N}$ loss process in spite of the great uncertainty associated with its measurement (Mosier et al., 1986). Nitrogen loss by $\mathrm{NO}_{3}-\mathrm{N}$ leaching from agricultural fields is a growing concern as elevated $\mathrm{NO}_{3}-\mathrm{N}$ levels are found in groundwater in many countries (Spalding and Exner, 1993; van der Ploeg et al., 1997; Diez et al., 2000). Zhang et al. (1996) used to find that at over half of 69 locations investigated, $\mathrm{NO}_{3}-\mathrm{N}$ concentrations in well water exceeded the allowable limit $\left(11.3 \mathrm{mg} \mathrm{N}^{-1}\right)$ by WHO and were positively correlated with fertilizer $\mathrm{N}$ rates across the Beijing-Tianjin-Tangshan region. $\mathrm{NO}_{3}-\mathrm{N}$ accumulation in the soil profile and its downward movement below 1-2 $\mathrm{m}$ depths have been shown for winter wheat (Westerman et al., 1994) and maize (MacGregor et al., 1974; Sogbedji et al., 2000) at higher N application rates. $\mathrm{NO}_{3}-\mathrm{N}$ leaching may thus occur under appropriate environmental conditions. In the UK, for example, increasing fertilizer $\mathrm{N}$ use has led to an increase of $36 \mathrm{~kg} \mathrm{~N}^{-1}$ per year in leachable nitrate on intensive wheat fields over the past 50 years (Davies and Sylvester-Bradley, 1995). In arable systems in Germany, the annual $\mathrm{N}$ leaching loss was $45 \mathrm{~kg} \mathrm{~N}^{-1}$ while the gaseous loss was $<20 \mathrm{~kg} \mathrm{~N}^{-1}$, although $\mathrm{N}$ immobilization in the lower topsoil has governed $\mathrm{N}$ balances since about the 1960s (Richter and Roelcke, 2000; Nieder et al., 1995).

However, there is a lack of in situ integrated studies on $\mathrm{N}$ dynamics, $\mathrm{N}$ budgets and $\mathrm{N}$ loss pathways under high fertilizer $\mathrm{N}$ inputs in winter wheat-maize cropping systems. Integrated research is essential to understand $\mathrm{N}$ behavior and balance in specific soil-crop systems. An in situ field study with irrigated winter wheat-maize rotation in the North China Plain was undertaken to investigate (1) the yield response to different $\mathrm{N}$ fertilizer rates under traditional irrigation and management systems; (2) dynamics and accumulation of inorganic $\mathrm{N}$ in the soil profile; (3) the $\mathrm{N}$ budget and pathways for $\mathrm{N}$ losses as related to the $\mathrm{N}$ application rate.

\section{Materials and methods}

\subsection{Experimental site}

A field experiment was conducted for 2 consecutive years (October 1998-September 2000) on a typical agricultural soil of the North China Plain (Meadow Aqualf) at the Campus Experimental Farm of China Agricultural University in Beijing. Before the 
Table 1

Precipitation $(\mathrm{mm})$ measured at the campus experimental station of CAU, Beijing, China

\begin{tabular}{lrrrc}
\hline & 1998 & 1999 & 2000 & 30 -year average \\
\hline January & 1 & 0 & 15 & 3 \\
February & 26 & 0 & 0 & 7 \\
March & 4 & 3 & 7 & 9 \\
April & 35 & 44 & 9 & 19 \\
May & 54 & 41 & 32 & 33 \\
June & 183 & 18 & 22 & 78 \\
July & 248 & 79 & 134 & 192 \\
August & 114 & 66 & 197 & 212 \\
September & 5 & 38 & 31 & 57 \\
October & 62 & 23 & 38 & 24 \\
November & 11 & 6 & 5 & 7 \\
December & 1 & 0 & 0 & 3 \\
Sum & 744 & 318 & 490 & 644 \\
\hline
\end{tabular}

experiment commenced, a winter wheat-maize rotation was grown from 1997 to 1998 without any NPK fertilizer inputs to make the soil at the field site homogeneous. The site is located at $39^{\circ} 57^{\prime} \mathrm{N}$ and $119^{\circ} 30^{\prime} \mathrm{E}$, and is $38 \mathrm{~m}$ above mean sea level at the north edge of the North China Plain. During the experiment, total and monthly precipitation values were clearly different from the 30-year average (Table 1). Selected soil profile characteristics are presented in Table 2. According to the local soil fertility classification in Beijing (Liu et al., 1999), the experimental soil is highly fertile. Prior to the experiment, continuous winter wheat-maize rotation was practiced using traditional tillage conditions for more than 10 years. The average grain yields were between 5 and $7 \mathrm{tha}^{-1}$ with rates of $210-320 \mathrm{~kg} \mathrm{~N}, 90-120 \mathrm{~kg} \mathrm{P}_{2} \mathrm{O}_{5}$ and $120-180 \mathrm{~kg} \mathrm{~K}_{2} \mathrm{O} \mathrm{ha}^{-1}$ (including both chemical fertilizers and organic manures) applied to each wheat or maize crop. Winter wheat usually requires three irrigation episodes (each of $75 \mathrm{~mm}$ water) while maize only requires supplemental irrigation especially during periods of dry weather. Crop management including inputs of pesticides and herbicides was conducted according to conventional agricultural practice.

\subsection{Fertilizer $N$ treatments}

Rates of $\mathrm{N}$ fertilizer as urea were $0,120,240$, and $360 \mathrm{~kg} \mathrm{~N} \mathrm{ha}^{-1}$ per crop, representing the unfertilized control (N0), the current recommended $\mathrm{N}$ rate (N120), the traditional $\mathrm{N}$ rate $(\mathrm{N} 240)$ and 1.5 times the traditional $\mathrm{N}$ rate $(\mathrm{N} 360)$. The plots, each $6 \mathrm{~m} \times 21 \mathrm{~m}$ in size, were arranged in a randomized complete block experimental design with three replicates. Fertilizer N was applied in two equal dressings for both winter wheat and maize. For winter wheat, half of the $\mathrm{N}$ was incorporated into the surface soil $(0-10 \mathrm{~cm})$ in early October prior to planting, and the other half broadcasted before sprinkler irrigation at shooting stage (mid-April). In the case of maize, half of the $\mathrm{N}$ was bandspread at the three-extended-leaf stage (early July) and the remainder was top-dressed prior to rainfall or sprinkler irrigation at the 10-extended-leaf stage (early August). The same amounts of P and K were applied to all plots as concentrated superphosphate and potassium sulfate. $60 \mathrm{~kg} \mathrm{P}_{2} \mathrm{O}_{5} \mathrm{ha}^{-1}$ was applied for winter wheat prior to planting and $60 \mathrm{~kg} \mathrm{P}_{2} \mathrm{O}_{5} \mathrm{ha}^{-1}$ and $60 \mathrm{~kg} \mathrm{~K}_{2} \mathrm{O} \mathrm{ha}^{-1}$ were applied for maize at the three-extended-leaf stage.

\subsection{Crop and soil management}

Winter wheat cultivar 'Nongda101' was planted in $25 \mathrm{~cm}$ rows at a rate of $180 \mathrm{~kg}$ seeds ha ${ }^{-1}$ between 5 and 9 October each year. After the harvest of winter wheat, a hybrid maize cultivar 'Nongda108' was

Table 2

Selected initial soil physicochemical characteristics at the experimental site

\begin{tabular}{|c|c|c|c|c|c|c|c|c|}
\hline $\begin{array}{l}\text { Soil depth } \\
(\mathrm{cm})\end{array}$ & $\begin{array}{l}\mathrm{pH} \\
\left(\mathrm{H}_{2} \mathrm{O}\right)\end{array}$ & $\begin{array}{l}\text { Organic } \\
\mathrm{C}\left(\mathrm{g} \mathrm{kg}^{-1}\right)\end{array}$ & $\begin{array}{l}\text { Total } \\
\mathrm{N}\left(\mathrm{g} \mathrm{kg}^{-1}\right)\end{array}$ & $\begin{array}{l}\text { Olsen } \\
\mathrm{P}\left(\mathrm{mg} \mathrm{kg}^{-1}\right)\end{array}$ & $\begin{array}{l}\mathrm{NH}_{4} \mathrm{OAc} \\
\mathrm{K}\left(\mathrm{mg} \mathrm{kg}^{-1}\right)\end{array}$ & $\begin{array}{l}\text { Sand } \\
(\%)\end{array}$ & $\begin{array}{l}\text { Silt } \\
(\%)\end{array}$ & $\begin{array}{l}\text { Clay } \\
(\%)\end{array}$ \\
\hline $0-20$ & 7.9 & 15.5 & 1.43 & 41.9 & 95.5 & 43 & 40 & 17 \\
\hline $20-40$ & 8.2 & 9.2 & 0.79 & 27.2 & 90.3 & 37 & 49 & 14 \\
\hline $40-60$ & 8.1 & 5.6 & 0.39 & 10.9 & 88.8 & 34 & 43 & 23 \\
\hline $60-80$ & 8.2 & 4.4 & 0.42 & 9.6 & 85.2 & 27 & 42 & 31 \\
\hline $80-100$ & 8.1 & 4.6 & 0.41 & 8.5 & 79.0 & 28 & 40 & 32 \\
\hline
\end{tabular}


planted with zero-tillage in $60 \mathrm{~cm}$ rows with $30 \mathrm{~cm}$ distance between every pair of adjacent plants with a density of 55000 seedlings $\mathrm{ha}^{-1}$ in the same permanent plots between 18 and 24 June. The selected varieties and the planting densities are popular in the local wheat-maize rotations. Water management was as follows. Winter wheat was irrigated prior to planting and at shooting stage with $75 \mathrm{~mm}$ water on each occasion (1998-1999 season), and at seedling, tillering, shooting and ear emergence stages with $75 \mathrm{~mm}$ water on each occasion (1999-2000 season). Maize was irrigated at seedling $(40 \mathrm{~mm})$ and 10-leaf stages $(60 \mathrm{~mm})$ in the 1999 season and irrigated at seedling stage only $(60 \mathrm{~mm})$ in 2000 . A sprinkler irrigation system with a water meter was used to ensure the uniform distribution and accurate control of irrigation water rate on each plot. The plants of each plot were harvested manually and aboveground crop residues except stubbles of both crops were removed from the plot during the 2-year period. The plant samples, comprising separate grain and straw from $1 \mathrm{~m}^{2}$ sampling area of wheat and five plants in the case of maize, were oven-dried at $65^{\circ} \mathrm{C}$ for 3 days. Grain and straw yields were recorded and grain data were adjusted to $14 \%$ moisture content. Concentrations of $\mathrm{N}$ in grain and straw samples of both wheat and maize were digested $\mathrm{H}_{2} \mathrm{SO}_{4}-\mathrm{H}_{2} \mathrm{O}_{2}$ solution and determined by the micro-Kjeldahl method (Bremner, 1996). N uptake $\left(\mathrm{kg} \mathrm{ha}^{-1}\right)$ by winter wheat and maize was estimated from the grain and straw dry matter yields multiplied by their $\mathrm{N}$ concentrations.

Dynamics of inorganic $\mathrm{N}$ as $\mathrm{NH}_{4}-\mathrm{N}$ and $\mathrm{NO}_{3}-\mathrm{N}$ in the soil profile were monitored by sampling three cores per plot with a $3 \mathrm{~cm}$ i.d. tube auger, and separating them into $20 \mathrm{~cm}$ depth increments. Sampling was done separately at 10 soil depths $(0-200 \mathrm{~cm})$ before planting and after harvest of winter wheat, and for 15 soil depths $(0-300 \mathrm{~cm})$ after harvest of maize in all $\mathrm{N}$ treatments during the 2-year study. Following the same protocol, soil samples were periodically taken from the upper five soil depths $(0-100 \mathrm{~cm})$ before and/or after important field operations during the first cycle of the winter wheat-maize rotation to monitor the dynamics of inorganic $\mathrm{N}$ during and after each crop.

Field moist soil samples were thoroughly mixed, and representative sub-samples were extracted immediately by shaking with $0.01 \mathrm{M} \mathrm{CaCl}_{2}$ solution
(1:10 soil:solution ratio) for $1 \mathrm{~h}$ on a rotary shaker $\left(180 \mathrm{rev} \mathrm{min}^{-1}\right)$ followed by filtration. The extracts were directly analyzed for $\mathrm{NH}_{4}-\mathrm{N}$ and $\mathrm{NO}_{3}-\mathrm{N}$ by an automated continuous flow analyzer (TRAACS 2000, Germany) or were stored at $-19{ }^{\circ} \mathrm{C}$ in a refrigerator until they were analyzed by the same method within 3 months. Bulk density $\left(D_{\mathrm{b}}\right)$ of the soils was determined to 200 (winter wheat) or $300 \mathrm{~cm}$ depth (maize) with $3 \mathrm{~cm}$ i.d. by $20 \mathrm{~cm}$ long steel corers with open ends following the soil sampling protocol described above for $\mathrm{N}$ dynamics. $\mathrm{NH}_{4}-\mathrm{N}$ and $\mathrm{NO}_{3}-\mathrm{N}$ concentrations ( $\mathrm{mg} \mathrm{kg}^{-1}$ soil) were converted to units of $\mathrm{kg} \mathrm{ha}^{-1}$ according to the mean $D_{\mathrm{b}}$ values of the different soil layers.

\subsection{Nitrogen budget}

A $\mathrm{N}$ budget was estimated for each plot for four growing periods of winter wheat and maize from October 1998 to September 2000. Soil $\mathrm{NH}_{4}-\mathrm{N}$ was not used in the $\mathrm{N}$ budget due to its relative stability throughout the crop rotation. Only the $0-100 \mathrm{~cm}$ soil profile was used for $\mathrm{NO}_{3}-\mathrm{N}$ in the $\mathrm{N}$ budget calculation as most of the crop roots were distributed in the 0-90 cm depth under the experimental conditions (Cao, 2002). For each period, the inputs to the budget consisted of initial soil $\mathrm{NO}_{3}-\mathrm{N}$ before planting, $\mathrm{N}$ mineralization and the applied fertilizer $\mathrm{N}$. N mineralization was estimated by the balance of inputs and outputs in the control (N0) treatment according to the following formula:

$$
\begin{aligned}
& \mathrm{N}_{\text {mineralization }} \\
& =\mathrm{N} \text { uptake from the control } \\
& \quad+\text { initial } 0-100 \mathrm{~cm} \text { soil } \mathrm{NO}_{3} \\
& \quad-\mathrm{N} \text { in the control }- \text { residual } 0-100{\mathrm{~cm} \mathrm{soil} \mathrm{NO}_{3}} \\
& \quad-\mathrm{N} \text { in the control }\left(\text { units : } \mathrm{kg} \mathrm{ha}^{-1}\right)
\end{aligned}
$$

Outputs consisted of plant $\mathrm{N}$ uptake, residual soil profile $\mathrm{NO}_{3}-\mathrm{N}$ and apparent $\mathrm{N}$ loss. The latter was attributed to the sum of $\mathrm{NO}_{3}-\mathrm{N}$ leaching, gaseous $\mathrm{N}$ emission as $\mathrm{NH}_{3}$ volatilization and denitrification, and the $\mathrm{N}$ unaccounted for (other $\mathrm{N}$ losses not determined). The increment of $\mathrm{NO}_{3}-\mathrm{N}$ accumulation below $100 \mathrm{~cm}$ soil depth in fertilizer $\mathrm{N}$ treatments for each growing season compared with the control was regarded as leaching loss in this budget calculation considering the distribution of roots and water movement in the soil 
profile. A semi open-static system (Nommik, 1973) was adapted to monitor $\mathrm{NH}_{3}$ volatilization loss from the plots as described by Beyrouty et al. (1988). However, the ammonia-trapping chamber used in this study was constructed from PVC pipe with inner dimensions measuring $15 \mathrm{~cm} \times 10 \mathrm{~cm}$ (diameter $\times$ height). Sheet PVC tabs, welded to each of the inner walls of the chambers at two levels, supported a lower sponge for $\mathrm{NH}_{3}$ volatilizing from fertilizer treatments and the upper sponge to prevent contamination from atmospheric $\mathrm{NH}_{3}$ using phosphoric acid/glycerine solution. The $\mathrm{NH}_{3}$ absorbed by the inner sponge was analyzed by TRAACS 2000 and $99.5 \%$ recovery was achieved in a preliminary trial (Wang et al., 2002). Ammonia volatilization in each $\mathrm{N}$ treatment was monitored only in the first cycle of winter wheatmaize rotation. Field denitrification in selected treatments (N0, N120 and N360) was monitored by a soil core incubation system using the $\mathrm{C}_{2} \mathrm{H}_{2}$-inhibition method (Ryden et al., 1987) during the 2-year study. Three soil cores $(0-15 \mathrm{~cm})$ were sampled and incubated for $24 \mathrm{~h}$ under $10 \% \mathrm{C}_{2} \mathrm{H}_{2}$ concentration and the $\mathrm{N}_{2} \mathrm{O}$ concentration was analyzed by a GC system (HP 5890II; Zou, 2001).

Statistical analysis of the data was accomplished by standard analysis of variance (ANOVA) and pairs of mean values compared by least significant difference (LSD) at the 5\% level using the SAS software package (SAS Institute, 1996).

\section{Results and discussion}

\subsection{Grain yields of winter wheat and maize}

The response of crops to fertilizer $\mathrm{N}$ mainly depends on soil $\mathrm{N}$ fertility, crop yield level and climatic conditions. In the first cycle of the rotation (1998-1999), grain yields of winter wheat $\left(6.2-6.4 \mathrm{t} \mathrm{ha}^{-1}\right)$ did not respond to applied $\mathrm{N}$ rate but significantly increased with increasing $\mathrm{N}$ rate in maize. The sole exception was grain yield in the $\mathrm{N} 240$ treatment, probably because soil $\mathrm{N}$ supply (e.g. initial $\mathrm{NO}_{3}-\mathrm{N}, \mathrm{N}$ mineralization and other $\mathrm{N}$ inputs from atmosphere and irrigation) sufficed for adequate growth of the first crop (Table 3). From the second rotation (1999-2000), however, grain yields of both crops (4.6-7.2 $\mathrm{t} \mathrm{ha}^{-1}$ for wheat and 6.0-7.5 $\mathrm{tha}^{-1}$ for maize) significantly increased with increasing
Table 3

Mean grain yields ( $\mathrm{t} \mathrm{ha}^{-1}$, adjusted to $14 \%$ moisture content) of winter wheat and maize under each $\mathrm{N}$ treatment in a 2-year winter wheat-maize cropping system ${ }^{\mathrm{a}}$

\begin{tabular}{lllll}
\hline & N0 & N120 & N240 & N360 \\
\hline 1998-1999 winter wheat & $6.19 \mathrm{a}$ & $6.38 \mathrm{a}$ & $6.36 \mathrm{a}$ & $6.38 \mathrm{a}$ \\
1999 maize & $4.15 \mathrm{a}$ & $4.88 \mathrm{~b}$ & $4.33 \mathrm{ab}$ & $4.81 \mathrm{~b}$ \\
1999-2000 winter wheat & $4.65 \mathrm{a}$ & $7.16 \mathrm{~b}$ & $6.40 \mathrm{~b}$ & $6.69 \mathrm{~b}$ \\
2000 maize & $6.04 \mathrm{a}$ & $7.07 \mathrm{~b}$ & $7.44 \mathrm{~b}$ & $7.48 \mathrm{~b}$ \\
\hline
\end{tabular}

${ }^{a}$ Values within the same crop followed by the same letter are not significantly different at 5\% level (method of LSD).

fertilizer $\mathrm{N}$ application as $\mathrm{N}$ became growth limiting (Table 3). Severe drought in 1999 particularly from July to September (as shown in Table 1) led to a significant decline in maize yields and a reduced $\mathrm{N}$ response in 1999 compared with those in 2000 under normal rainfall conditions (Table 3). Water stress was almost certainly the main reason for the lack of response of maize to applied N. Winter wheat and maize yields were not significantly different among the three $\mathrm{N}$ application rates $(\mathrm{N} 120, \mathrm{~N} 240, \mathrm{~N} 360)$ in 2 years of the rotation, suggesting that $\mathrm{N}$ application exceeding $120 \mathrm{~kg} \mathrm{~N}^{-1}$ did not further increase crop yields. In addition, the levels 240 and $360 \mathrm{~kg} \mathrm{~N}^{-1}$ were beyond the $\mathrm{N}$ requirements of the two crop species at these grain yield levels. Considering the high available $\mathrm{P}$ and $\mathrm{K}$ levels in our experimental soil, these two nutrients would be very unlikely to limit grain yields of wheat and maize particularly under high $\mathrm{N}$ levels. No $\mathrm{Zn}$ or other micronutrient deficiency symptoms in maize or wheat were observed during the 2-year study. Thus, the availability of micronutrients in the soil is unlikely to be the yield-limiting factor as well.

Many other studies in China have also confirmed that both winter wheat and maize seldom respond to $\mathrm{N}$ rates higher than $120-180 \mathrm{~kg} \mathrm{~N} \mathrm{ha}^{-1}$ in spite of different crop varieties (Chen et al., 2000; Zhou et al., 2001; Zhu, 1998). In Germany, similar yield response to $\mathrm{N}$ supply was observed by Blankenau and Kuhlmann (2000), who found a small decline in grain yields of winter wheat and barley when $0-90 \mathrm{~cm}$ $\mathrm{N}_{\text {min }}+$ fertilizer $\mathrm{N}>190-220 \mathrm{~kg} \mathrm{~N} \mathrm{ha}^{-1}$. Therefore, the very high $\mathrm{N}$ application rate used in the area could not produce greater grain yields but probably led to substantially more $\mathrm{N}$ loss compared with the recommended $\mathrm{N}$ rate as discussed later. 


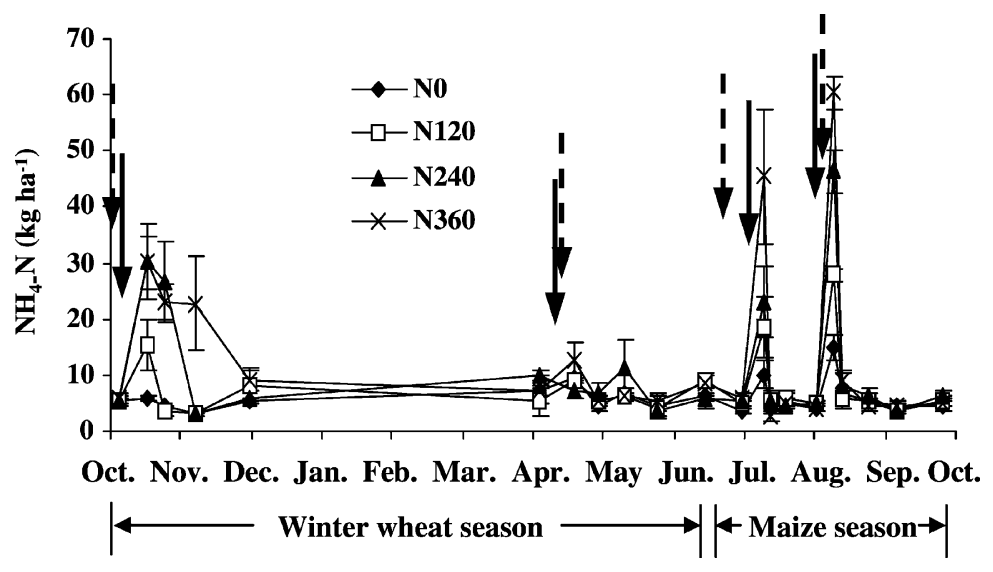

Fig. 1. Dynamics of $\mathrm{NH}_{4}-\mathrm{N}$ in the topsoil $(0-20 \mathrm{~cm})$ as affected by $\mathrm{N}$ application rate in the first cycle of a winter wheat-maize cropping system (1998-1999). Solid arrows denote fertilizer N application and dotted arrows denote irrigation. Bars = S.E.M (standard error of mean).

\subsection{Dynamics of soil inorganic $N$}

After application of fertilizer $\mathrm{N}$ as urea, soil $\mathrm{NH}_{4}-\mathrm{N}$ increased drastically due to the rapid hydrolysis of the urea, then declined to its original level as nitrification occurred. In winter wheat, $\mathrm{NH}_{4}-\mathrm{N}$ in the topsoil $(0$ $20 \mathrm{~cm}$ layer) peaked at 6 days after the basal application was incorporated into the soil, and then it dropped to the level of the control within the next 14-21 days, depending on the rate of fertilizer $\mathrm{N}$ (Fig. 1). The change in $\mathrm{NH}_{4}-\mathrm{N}$ in the same layer was less pronounced when urea was applied as topdressing (with irrigation) at the shooting stage (Fig. 1), presumably due to higher soil temperature and moisture (Parker and Larson, 1962). This was quite similar to our previous results (Liu et al., 2001). During the maize season, $\mathrm{NH}_{4}-\mathrm{N}$ in the topsoil changed more rapidly by $\mathrm{N}$ applications (Fig. 1) mainly due to the high nitrification rate in the summer season. Little change was observed in the lower soil layers $(20-100 \mathrm{~cm})$ throughout the whole cropping year (data not shown). It appears that the dynamics of $\mathrm{NH}_{4}-\mathrm{N}$ in the profile of these upland soils can therefore be disregarded for calculation of $\mathrm{N}$ recommendations and $\mathrm{N}$ budgets.

In contrast, $\mathrm{NO}_{3}-\mathrm{N}$ in the soil profile was greatly altered by the $\mathrm{N}$ application rate (Fig. 2). $\mathrm{NO}_{3}-\mathrm{N}$ levels in all soil layers $(0-100 \mathrm{~cm}$ profile) remained at a very low level in the control during the entire rotation with the exception of a slight increase in $\mathrm{NO}_{3}-\mathrm{N}$ in the topsoil in mid-October 1998, presumably due to tillage (ploughing) enhancing mineralization of organic
$\mathrm{N}$ in this soil layer. In the N120 treatment, only the topsoil $\mathrm{NO}_{3}-\mathrm{N}$ significantly increased after fertilizer application over the control showing that the amount of $\mathrm{NO}_{3}-\mathrm{N}$ entering into $20-100 \mathrm{~cm}$ profile at this relatively low $\mathrm{N}$ level did not exceed crop uptake. In the $\mathrm{N} 240$ and $\mathrm{N} 360$ treatments, $\mathrm{NO}_{3}-\mathrm{N}$ in all soil layers increased after application of fertilizer N. Topsoil $\mathrm{NO}_{3}-\mathrm{N}$ in the two $\mathrm{N}$ treatments remained at very high levels (60-120 $\mathrm{kg} \mathrm{ha}^{-1}$ ) during the whole winter wheat-maize cropping season (Fig. $2 \mathrm{~A}$ ). $\mathrm{NO}_{3}-\mathrm{N}$ in other subsoil layers increased significantly after the second $\mathrm{N}$ application in the winter wheat season compared to the control and N120, suggesting a large amount of $\mathrm{NO}_{3}-\mathrm{N}$ moving into deeper soil layers after the shooting stage of winter wheat (Fig. $2 \mathrm{~B}$ and $\mathrm{C}$ ). The change in $\mathrm{NO}_{3}-\mathrm{N}$ at a soil depth of $0-100 \mathrm{~cm}$ was much greater during the maize crop than winter wheat, indicating a relatively pronounced movement of $\mathrm{NO}_{3}$ $\mathrm{N}$ in the soil profile during the summer when rainfall peaked (Fig. 2).

\subsection{Accumulation and leaching of $\mathrm{NO}_{3}-\mathrm{N}$}

The amounts of $\mathrm{NO}_{3}-\mathrm{N}$ in the soil profile varied greatly among experimental years and crops (Table 4). $\mathrm{NO}_{3}-\mathrm{N}$ in $0-200$ (wheat) or $0-300 \mathrm{~cm}$ (maize) of the soil profile increased with increasing $\mathrm{N}$ rate and over time. After the winter wheat harvest (1998-1999), the amounts of $\mathrm{NO}_{3}-\mathrm{N}$ in $0-100$ and $100-200 \mathrm{~cm}$ layers in N240 and N360 increased markedly compared with the control and even the original $\mathrm{NO}_{3}-\mathrm{N}$ before the 


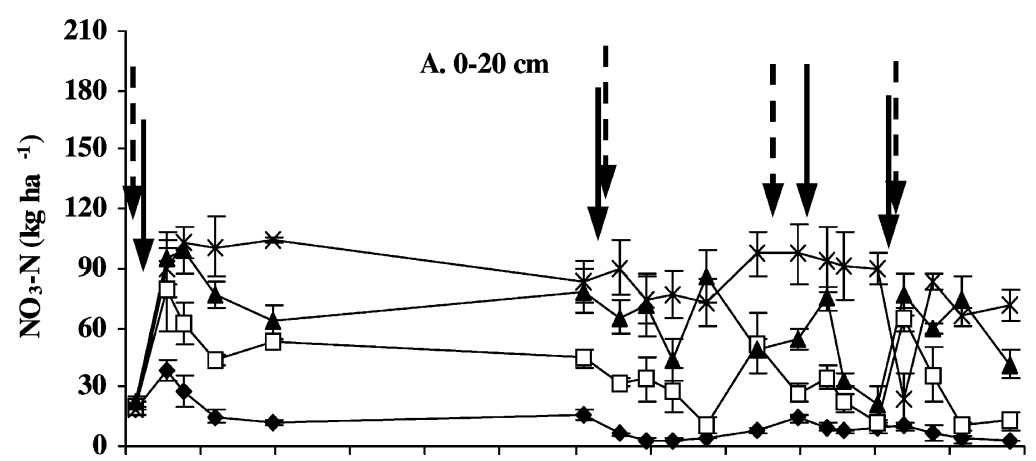

Oct. Nov. Dec. Jan. Feb. Mar. Apr. May Jun. Jul. Aug. Sep. Oct.

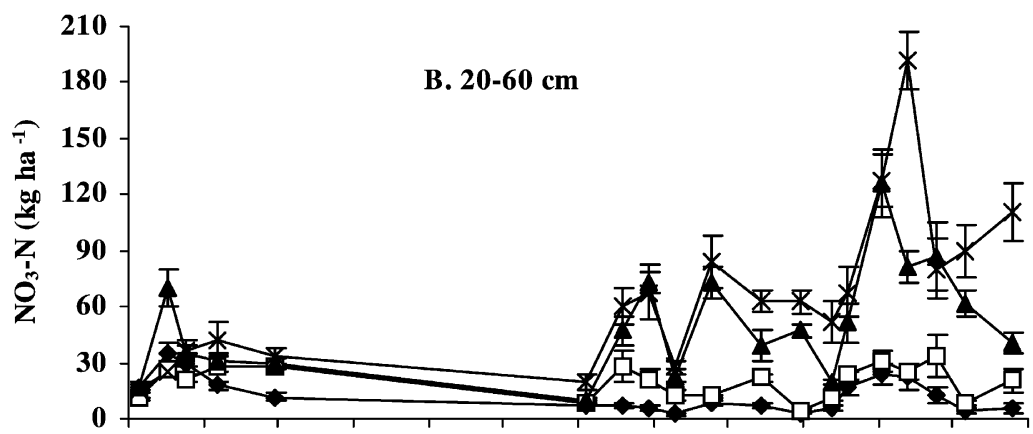

Oct. Nov. Dec. Jan. Feb. Mar. Apr. May Jun. Jul. Aug. Sep. Oct.

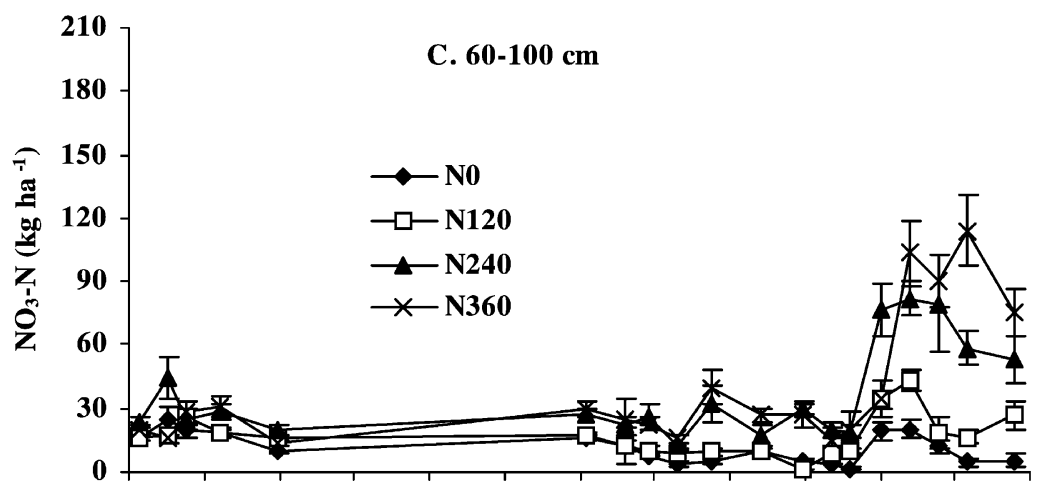

Oct. Nov. Dec. Jan. Feb. Mar. Apr. May Jun. Jul. Aug. Sep. Oct.

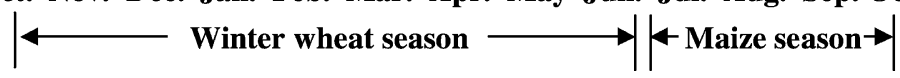

Fig. 2. Dynamics of $\mathrm{NO}_{3}-\mathrm{N}$ in different soil depths $(0-20,20-60$ and $60-100 \mathrm{~cm})$ as affected by $\mathrm{N}$ application rate in the first cycle of a winter wheat-maize cropping system (1998-1999). Solid arrows denote fertilizer N application and dotted arrows denote irrigation. Bars = S.E.M.

trial, while the amounts of $\mathrm{NO}_{3}-\mathrm{N}$ in corresponding layers in N120 were not significantly different from the original $\mathrm{NO}_{3}-\mathrm{N}$ level. In the first rotation cycle (1998-1999), $\mathrm{NO}_{3}-\mathrm{N}$ accumulated mainly in the top $200 \mathrm{~cm}$ of the soil profile and the accumulation of $\mathrm{NO}_{3}-\mathrm{N}$ below this layer was not significantly different among four $\mathrm{N}$ levels, indicating that negligible amounts of $\mathrm{NO}_{3}-\mathrm{N}$ were leached out of the top $200 \mathrm{~cm}$ of the profile in the first rotation cycle (Fig. 3). In the second rotation cycle (1999-2000), the accumulation of $\mathrm{NO}_{3}-\mathrm{N}$ in the soil profile increased continuously, especially in the N240 and N360 treatments (Fig. 3). 
Table 4

$\mathrm{NO}_{3}$-N leaching losses $\left(\mathrm{kg} \mathrm{ha}^{-1}\right)$ in a 2-year winter wheat-maize cropping system ${ }^{\mathrm{a}}$

\begin{tabular}{|c|c|c|c|c|}
\hline & No & N120 & $\mathrm{N} 240$ & N360 \\
\hline \multicolumn{5}{|l|}{ After harvest of 1998-1999 wheat } \\
\hline $\mathrm{NO}_{3}-\mathrm{N}$ accumulation below $100 \mathrm{~cm}$ & $18 \mathrm{a}$ & $40 \mathrm{a}$ & $135 \mathrm{~b}$ & $184 \mathrm{c}$ \\
\hline Accumulated leaching as fertilizer $\mathrm{N}$ & - & $22 \mathrm{a}$ & $117 \mathrm{~b}$ & $166 \mathrm{~b}$ \\
\hline Leaching in 1998-1999 wheat season & - & $22 \mathrm{a}$ & $117 \mathrm{~b}$ & $166 \mathrm{~b}$ \\
\hline \multicolumn{5}{|l|}{ After harvest of 1999 maize } \\
\hline $\mathrm{NO}_{3}-\mathrm{N}$ accumulation below $100 \mathrm{~cm}$ & $72 \mathrm{a}$ & $115 \mathrm{a}$ & $227 \mathrm{~b}$ & $254 \mathrm{~b}$ \\
\hline Accumulated leaching as fertilizer $\mathrm{N}$ & - & $43 \mathrm{a}$ & $155 \mathrm{~b}$ & $182 \mathrm{~b}$ \\
\hline Leaching in 1999 maize season & - & $21 \mathrm{a}$ & $38 \mathrm{a}$ & $16 \mathrm{a}$ \\
\hline \multicolumn{5}{|l|}{ After harvest of 1999-2000 wheat } \\
\hline $\mathrm{NO}_{3}-\mathrm{N}$ accumulation below $100 \mathrm{~cm}$ & $32 \mathrm{a}$ & $82 \mathrm{a}$ & $249 \mathrm{~b}$ & $345 \mathrm{c}$ \\
\hline Accumulated leaching as fertilizer $\mathrm{N}$ & - & $50 \mathrm{a}$ & $217 \mathrm{~b}$ & $313 \mathrm{~b}$ \\
\hline Leaching in 1999-2000 wheat season & - & $7 \mathrm{a}$ & $62 \mathrm{ab}$ & $131 \mathrm{~b}$ \\
\hline \multicolumn{5}{|l|}{ After harvest of 2000 maize } \\
\hline $\mathrm{NO}_{3}-\mathrm{N}$ accumulation below $100 \mathrm{~cm}$ & 64 a & $194 \mathrm{~b}$ & $385 \mathrm{c}$ & $574 \mathrm{~d}$ \\
\hline Accumulated leaching as fertilizer $\mathrm{N}$ & - & $120 \mathrm{a}$ & $321 \mathrm{~b}$ & $510 \mathrm{c}$ \\
\hline Leaching in 2000 maize season & - & $70 \mathrm{a}$ & $104 \mathrm{a}$ & $197 \mathrm{~b}$ \\
\hline
\end{tabular}

${ }^{\text {a }}$ Values within the same row with the same letters are not significantly different at the $5 \%$ level.

After the winter wheat harvest (1999-2000), the total amount of $\mathrm{NO}_{3}-\mathrm{N}$ in the $0-200 \mathrm{~cm}$ soil layers were 499 and $675 \mathrm{~kg} \mathrm{ha}^{-1}$ in N240 and N360, respectively, significantly higher than those of the control and N120 (Fig. 3). After the maize harvest in $2000, \mathrm{NO}_{3}-\mathrm{N}$ accumulation amounted to 657 and $865 \mathrm{~kg} \mathrm{ha}^{-1}$ at $0-200 \mathrm{~cm}$ and to 158 and $276 \mathrm{~kg} \mathrm{ha}^{-1}$ in the 200 $300 \mathrm{~cm}$ layer at the high $\mathrm{N}$ levels (Fig. 3). This indicates that much larger amounts of $\mathrm{NO}_{3}-\mathrm{N}$ in N240 and N360 were leached out of the top $200 \mathrm{~cm}$ of soil compared to the control and N120.

Both cumulative $\mathrm{NO}_{3}-\mathrm{N}$ leaching and $\mathrm{NO}_{3}-\mathrm{N}$ leaching per crop are shown in Table 4. The $\mathrm{NO}_{3}-\mathrm{N}$ leaching in N120, which ranged from 7 to $70 \mathrm{~kg} \mathrm{ha}^{-1}$, was relatively small during the four crop seasons (Table 4). The amounts of $\mathrm{NO}_{3}-\mathrm{N}$ leaching increased markedly under high N levels (N240 and N360). Much greater $\mathrm{NO}_{3}-\mathrm{N}$ leaching was observed in $\mathrm{N} 240$ and N360 treatments in all crop seasons with the exception of the 1999 maize season when dry weather conditions probably limited the movement of water and nitrate in the soil profile (as seen in Table 1). In this study, irrigation promoted the downward movement of $\mathrm{NO}_{3}$ $\mathrm{N}$ in the soil profile. As seen in Fig. 2, each irrigation event caused a rapid decline in $\mathrm{NO}_{3}-\mathrm{N}$ in the topsoil and an increase in the subsoil. However, $\mathrm{NO}_{3}-\mathrm{N}$ leaching below $200 \mathrm{~cm}$ soil depth was mainly driven by the rainfall, particularly in the 2000 summer season (Table 1). Significant leaching of $\mathrm{NO}_{3}-\mathrm{N}$ from the root zone $(100 \mathrm{~cm}$ depth) under winter wheat occurred only under high N levels (Table 4), and would have been considered to be very unlikely at lower application rates (Yuan et al., 1995). Large $\mathrm{NO}_{3}-\mathrm{N}$ accumulations below $2 \mathrm{~m}$ soil layers have been reported frequently under high $\mathrm{N}$ rates in the same winter wheat-maize cropping systems (Lu et al., 1998) and in vegetable cropping systems (Yuan, 1999) in northern China. These observations clearly indicate that the accumulation in the subsoil and leaching of $\mathrm{NO}_{3}-\mathrm{N}$ to the groundwater may be a serious environmental issue in the high $\mathrm{N}$ input regions of China. Further studies would be needed to trace the fate of the $\mathrm{NO}_{3}-\mathrm{N}$ that has accumulated in the subsoil.

\subsection{Gaseous $\mathrm{N}$ losses by $\mathrm{NH}_{3}$ volatilization and denitrification}

Gaseous $\mathrm{N}$ losses by $\mathrm{NH}_{3}$ volatilization and denitrification are illustrated in Table $5 . \mathrm{NH}_{3}$ volatilization as fertilizer $\mathrm{N}$ ranged from 3 to $34 \mathrm{~kg} \mathrm{ha}^{-1}$ in winter wheat and 7-19 $\mathrm{kg} \mathrm{ha}^{-1}$ in maize, and the total volatilization losses were 10,21 and $53 \mathrm{~kg} \mathrm{ha}^{-1}$ (equivalent to $4-7 \%$ of total fertilizer N) in N120, N240 and $\mathrm{N} 360$, respectively, in the first rotation cycle (Table 5). 

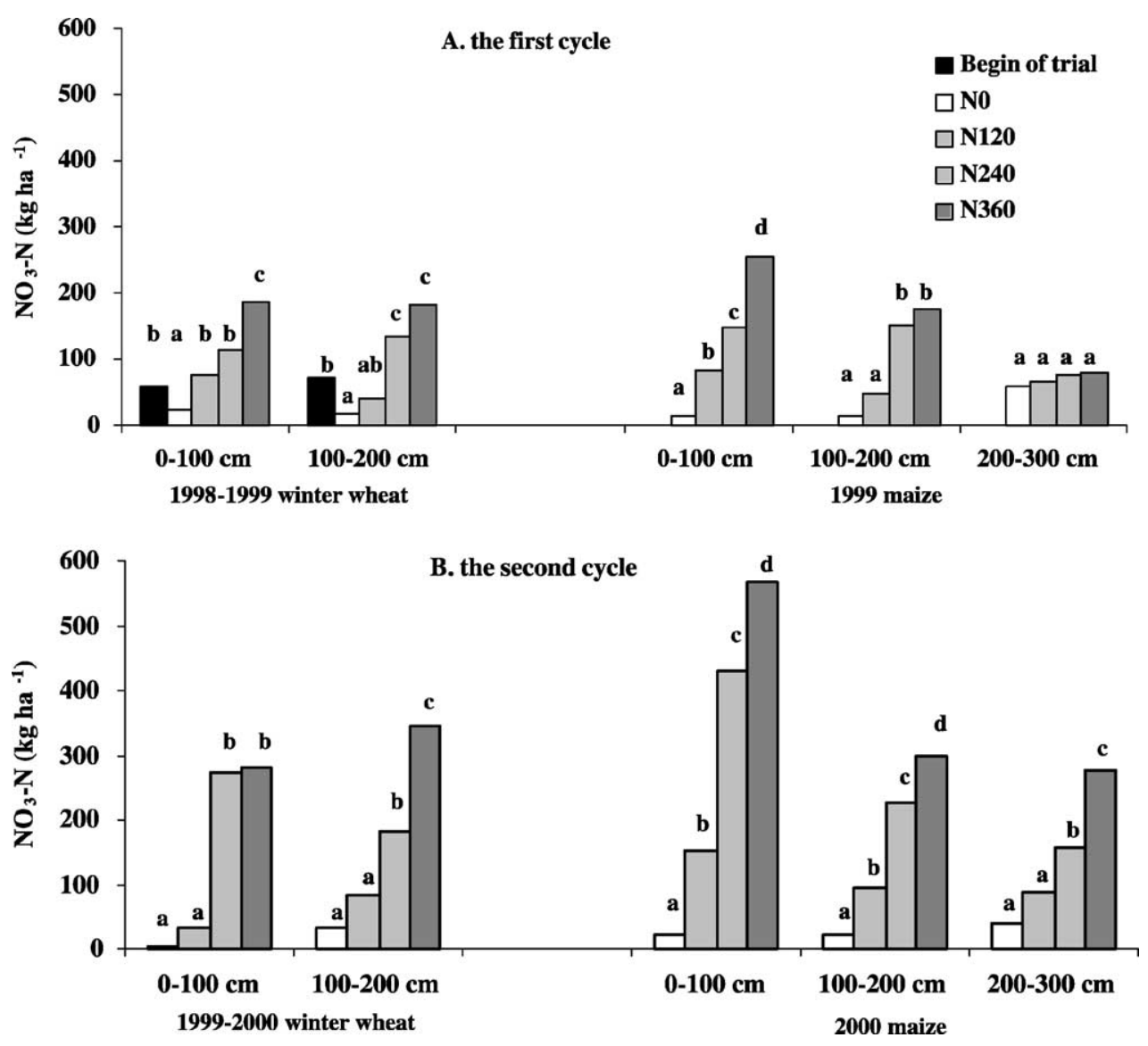

Fig. 3. Accumulation of $\mathrm{NO}_{3}-\mathrm{N}$ in the $0-200 \mathrm{~cm}$ and/or $0-300 \mathrm{~cm}$ soil profile at the beginning of the trial and after the harvest of winter wheat and maize during the two cycles of rotation (1998-2000). Values within the same column with same letters are not significantly different at the 5\% level.

We assume that similar volatilization losses occurred at the same $\mathrm{N}$ application rates in both the 1999 and 2000 growth seasons of wheat and maize but $\mathrm{NH}_{3}$ volatilization was not measured in the second rotation cycle. The volatilization losses measured were somewhat lower than the average losses estimated on calcareous upland soils in China (9\%) estimated by Xing and Zhu (2000). However, the volatilization losses in this study may have reflected the actual losses more closely because the urea used was incorporated in top $10 \mathrm{~cm}$ of the soil or top-dressed with irrigation or rainfall, thus lowering $\mathrm{NH}_{3}$ volatilization compared with surface application (Cai, 1997; Zhu and Chen, 2002).

Denitrification losses were negligible in winter wheat and were small and variable in maize $\left(6-8 \mathrm{~kg} \mathrm{ha}^{-1}\right.$ in 1999 and $12-19 \mathrm{~kg} \mathrm{ha}^{-1}$ in 2000) under different $\mathrm{N}$ rates (Table 5). This variation is thought to be mainly due to the change in rainfall between experimental years (Table 1). Similarly, Sanchez et al. (2001) reported that $10 \%$ of $\mathrm{N}$ applied as urea $\left(40.7 \mathrm{~kg} \mathrm{ha}^{-1}\right)$ was lost by denitrification mainly during the maize cropping period in central Spain. It should be pointed out that the denitrification losses determined using the direct method are often lower than those estimated using the indirect method (the difference method). New direct methods are required that account for the rapid spatial and temporal variability of denitrification in the field (Ryden and Rolston, 1983).

\subsection{Nitrogen budgets}

For sustainable land use, nutrient budgets have to be balanced to avoid negative impacts on the environment, 
Table 5

Gaseous $\mathrm{N}$ losses $\left(\mathrm{kg} \mathrm{ha}^{-1}\right)$ by $\mathrm{NH}_{3}$ volatilization and denitrification in a 2-year winter wheat-maize cropping system

\begin{tabular}{llll}
\hline & $\mathrm{N} 120$ & $\mathrm{~N} 240$ & $\mathrm{~N} 360$ \\
\hline $\begin{array}{lll}\mathrm{NH}_{3} \text { volatilization } \\
\text { 1998-1999 wheat }\end{array}$ & $3 \mathrm{a}^{\mathrm{a}}$ & $9 \mathrm{a}$ & $34 \mathrm{~b}$ \\
1999 maize & $7 \mathrm{a}$ & $12 \mathrm{ab}$ & $19 \mathrm{~b}$ \\
Sum & $10 \mathrm{a}$ & $21 \mathrm{a}$ & $53 \mathrm{~b}$ \\
& & & \\
$\begin{array}{l}\text { Denitrification } \\
\text { 1998-1999 wheat }\end{array}$ & tr. & n.d. & tr. \\
1999 maize & $6 \mathrm{a}$ & n.d. & $8 \mathrm{a}$ \\
Sum & $6 \mathrm{a}$ & n.d. & $8 \mathrm{a}$ \\
$1999-2000$ wheat & tr. & n.d. & tr. \\
2000 maize & $12 \mathrm{a}$ & n.d. & $19 \mathrm{~b}$ \\
Sum & $12 \mathrm{a}$ & n.d. & $19 \mathrm{~b}$ \\
\hline
\end{tabular}

${ }^{a}$ Values within the same row with the same letters are not significantly different at the $5 \%$ level.

${ }^{\mathrm{b}}$ Not determined.

especially in high-yielding systems. We therefore calculated the $\mathrm{N}$ budget for each growing season and both crops from the top $100 \mathrm{~cm}$ soil layer during the experimental period (October 1998-September 2000) and the results are presented in Table 6 together with measured $\mathrm{N}$ losses by $\mathrm{NO}_{3}-\mathrm{N}$ leaching and gaseous $\mathrm{N}$ emissions. The results show that $\mathrm{N}$ mineralization (91-153 $\mathrm{kg} \mathrm{ha}^{-1}$ per crop) was a significant input from the highly fertile soil particularly in the wet summer season. This source of $\mathrm{N}$ often determines crop response to $\mathrm{N}$ fertilizer. Under similar

Table 6

Nitrogen budget $\left(\mathrm{kg} \mathrm{ha}^{-1}\right)$ showing $\mathrm{N}$ inputs (initial soil $\mathrm{NO}_{3}-\mathrm{N}$, applied $\mathrm{N}$ and $\mathrm{N}$ mineralization) and $\mathrm{N}$ outputs ( $\mathrm{N}$ uptake, residual $\mathrm{NO}_{3}-\mathrm{N}$, and apparent $\mathrm{N}$ loss) together with measured $\mathrm{N}$ losses in a 2-year winter wheat-maize cropping system

\begin{tabular}{lcccc}
\hline & $\mathrm{N} 0$ & $\mathrm{~N} 120$ & $\mathrm{~N} 240$ & $\mathrm{~N} 360$ \\
\hline 1998-1999 wheat season & & & & \\
$\quad$ Initial soil $\mathrm{NO}_{3}$-N & 57 & 57 & 57 & 57 \\
Applied N & 0 & 120 & 240 & 360 \\
$\mathrm{~N}$ mineralization & 91 & 91 & 91 & 91 \\
Plant N uptake & $124 \mathrm{a}^{\mathrm{b}}$ & $149 \mathrm{~b}$ & $155 \mathrm{~b}$ & $163 \mathrm{~b}$ \\
Residual soil $\mathrm{NO}_{3}-\mathrm{N}$ & $24 \mathrm{a}$ & $85 \mathrm{ab}$ & $106 \mathrm{~b}$ & $186 \mathrm{c}$ \\
Apparent N loss & 0 & 34 & 127 & 159 \\
$\quad(=1+2+3-4-5)$ & & & & \\
$\mathrm{NO}_{3}-\mathrm{N}$ leaching & - & 22 & 117 & 166 \\
Gaseous N emission $^{\text {Unaccounted for }}{ }^{\mathrm{a}}$ & - & 3 & 9 & 34 \\
& - & 9 & 1 & -41
\end{tabular}

Table 6 (Continued)

\begin{tabular}{|c|c|c|c|c|}
\hline & No & N120 & $\mathrm{N} 240$ & N360 \\
\hline \multicolumn{5}{|l|}{1999 maize season } \\
\hline Initial soil $\mathrm{NO}_{3}-\mathrm{N}$ & $24 \mathrm{a}$ & $85 \mathrm{ab}$ & $106 \mathrm{~b}$ & $186 \mathrm{c}$ \\
\hline Applied N & 0 & 120 & 240 & 360 \\
\hline $\mathrm{N}$ mineralization & 95 & 95 & 95 & 95 \\
\hline Plant N uptake & $106 \mathrm{a}$ & $138 \mathrm{~b}$ & $141 \mathrm{~b}$ & $147 \mathrm{~b}$ \\
\hline Residual soil $\mathrm{NO}_{3}-\mathrm{N}$ & $13 \mathrm{a}$ & $82 \mathrm{ab}$ & $149 \mathrm{~b}$ & $256 \mathrm{c}$ \\
\hline $\begin{array}{l}\text { Apparent } \mathrm{N} \text { loss } \\
\quad(=1+2+3-4-5)\end{array}$ & 0 & 80 & 151 & 238 \\
\hline $\mathrm{NO}_{3}-\mathrm{N}$ leaching & - & 21 & 38 & 16 \\
\hline Gaseous $\mathrm{N}$ emission & - & 13 & 12 & 27 \\
\hline Unaccounted for & - & 46 & 101 & 195 \\
\hline \multicolumn{5}{|l|}{ 1999-2000 wheat season } \\
\hline Initial soil $\mathrm{NO}_{3}-\mathrm{N}$ & $13 \mathrm{a}$ & $82 \mathrm{ab}$ & $149 \mathrm{~b}$ & $256 \mathrm{c}$ \\
\hline Applied N & 0 & 120 & 240 & 360 \\
\hline $\mathrm{N}$ mineralization & 91 & 91 & 91 & 91 \\
\hline Plant N uptake & 98 a & $175 \mathrm{~b}$ & $179 \mathrm{~b}$ & $177 \mathrm{~b}$ \\
\hline Residual soil $\mathrm{NO}_{3}-\mathrm{N}$ & $6 a$ & $44 \mathrm{a}$ & $250 \mathrm{~b}$ & $330 \mathrm{~b}$ \\
\hline $\begin{array}{l}\text { Apparent } \mathrm{N} \text { loss } \\
\quad(=1+2+3-4-5)\end{array}$ & 0 & 74 & 51 & 200 \\
\hline $\mathrm{NO}_{3}-\mathrm{N}$ leaching & - & 7 & 62 & 131 \\
\hline Gaseous $\mathrm{N}$ emission $^{\mathrm{c}}$ & - & tr. & n.d. ${ }^{\mathrm{d}}$ & tr. \\
\hline Unaccounted for & - & 67 & -9 & 69 \\
\hline \multicolumn{5}{|l|}{2000 maize season } \\
\hline Initial soil $\mathrm{NO}_{3}-\mathrm{N}$ & $6 \mathrm{a}$ & $44 \mathrm{a}$ & $250 \mathrm{~b}$ & $330 \mathrm{~b}$ \\
\hline Applied N & 0 & 120 & 240 & 360 \\
\hline $\mathrm{N}$ mineralization & 153 & 153 & 153 & 153 \\
\hline Plant $\mathrm{N}$ uptake & $136 \mathrm{a}$ & $173 \mathrm{~b}$ & $182 \mathrm{~b}$ & $182 \mathrm{~b}$ \\
\hline Residual soil $\mathrm{NO}_{3}-\mathrm{N}$ & $23 \mathrm{a}$ & $152 \mathrm{~b}$ & $430 \mathrm{c}$ & $567 \mathrm{~d}$ \\
\hline $\begin{array}{l}\text { Apparent } \mathrm{N} \text { loss } \\
\quad(=1+2+3-4-5)\end{array}$ & 0 & -8 & 31 & 94 \\
\hline $\mathrm{NO}_{3}-\mathrm{N}$ leaching & - & 70 & 104 & 197 \\
\hline Gaseous $\mathrm{N}$ emission & - & 12 & n.d. & 19 \\
\hline Unaccounted for & - & -90 & -73 & -122 \\
\hline
\end{tabular}

Two cycles of wheat-maize rotation (1998-2000)

\begin{tabular}{lcccc} 
Initial soil $\mathrm{NO}_{3}-\mathrm{N}$ & 57 & 57 & 57 & 57 \\
Applied N & 0 & 480 & 960 & 1440 \\
$\mathrm{~N}$ mineralization & 430 & 430 & 430 & 430 \\
Plant $\mathrm{N}$ uptake & $464 \mathrm{a}$ & $635 \mathrm{~b}$ & $657 \mathrm{~b}$ & $669 \mathrm{~b}$ \\
Residual soil $\mathrm{NO}_{3}-\mathrm{N}$ & $23 \mathrm{a}$ & $152 \mathrm{~b}$ & $430 \mathrm{c}$ & $567 \mathrm{~d}$ \\
Apparent $\mathrm{N}$ loss & 0 & 180 & 360 & 691 \\
$\quad(=1+2+3-4-5)$ & & & & \\
$\quad \mathrm{NO}_{3}-\mathrm{N}$ leaching & - & 120 & 321 & 510 \\
$\quad$ Gaseous N emission & - & 28 & 21 & 79 \\
$\quad$ Unaccounted for & - & 32 & 18 & 102 \\
\hline
\end{tabular}

a The rest $\mathrm{N}$ loss could not be included in $\mathrm{NO}_{3}-\mathrm{N}$ leaching and gaseous $\mathrm{N}$ emissions.

${ }^{\mathrm{b}}$ Values within the same soil layer with the same letters are not significantly different at the $5 \%$ level.

${ }^{\mathrm{c}} \mathrm{NH}_{3}$ volatilization in the second rotation cycle was not measured.

${ }^{\mathrm{d}}$ Denitrification was not measured during the two cycles of wheat-maize rotation in the treatment (N240). 
maize-wheat-maize sequences, Diez et al. (1997) also reported high rates of $\mathrm{N}$ mineralization, particularly when soil temperature and moisture were favorable. It should be pointed out that the $\mathrm{N}$ mineralization in our study included the $\mathrm{N}$ from environment (e.g. $\mathrm{N}$ deposition and biological $\mathrm{N}$ fixation) as well.

Most of the $\mathrm{N}$ uptake by winter wheat and maize exceeded the low N application rate (N120) but was less than the traditional $\mathrm{N}$ rate (N240), typically ranging from 100 to $180 \mathrm{~kg} \mathrm{ha}^{-1}$ (Table 5). Crop $\mathrm{N}$ uptake significantly increased with increasing $\mathrm{N}$ rate, but further fertilizer $\mathrm{N}$ inputs beyond $120 \mathrm{~kg} \mathrm{~N}^{-1}$ did not lead to significant increases in $\mathrm{N}$ uptake (Table 6). The lack of response of plant $\mathrm{N}$ uptake to higher application rates indicates that the extra $\mathrm{N}$ from the two highest $\mathrm{N}$ rates studied is very poorly utilized by winter wheat and maize, as crop yields did not differ between these $\mathrm{N}$ treatments (Table 3). In both crops, the lower rate of $\mathrm{N}$ applied by the N120 treatment prevented waste of $\mathrm{N}$ fertilizer by matching crop $\mathrm{N}$ requirements better than the N240 and N360 treatments at local yield levels. This conclusion is supported by the results of $\mathrm{NO}_{3}-\mathrm{N}$ accumulation in the soil profile (Fig. 3) and the apparent $\mathrm{N}$ losses (Table 6).

Estimates of inputs and outputs of the $\mathrm{N}$ budget (Table 5) indicate that the variation in $\mathrm{NO}_{3}-\mathrm{N}$ was related mainly to the applied $\mathrm{N}$ rates in the cropping system. In October 1998 (at start of the trial), $57 \mathrm{~kg} \mathrm{ha}^{-1}$ soil $\mathrm{NO}_{3}-\mathrm{N}$ was present in the $0-100 \mathrm{~cm}$ depth for all $\mathrm{N}$ levels, while the residual soil $\mathrm{NO}_{3}-\mathrm{N}$ after the maize harvest in 2000 was 23, 152, 430 and $567 \mathrm{~kg} \mathrm{ha}^{-1}$ for the control, N120, N240 and N360 treatments, respectively. Apparent $\mathrm{N}$ losses drastically increased with increasing $\mathrm{N}$ rate, particularly when the $\mathrm{N}$ rate exceeded $120 \mathrm{~kg} \mathrm{~N} \mathrm{ha}^{-1}$ (Table 6), indicating that fertilizer $\mathrm{N}$ losses occurred mainly under high inputs of fertilizer $\mathrm{N}$.

During the 1998-1999 winter wheat growing season, the apparent $\mathrm{N}$ losses amounted to only $34 \mathrm{~kg} \mathrm{ha}^{-1}$ in $\mathrm{N} 120$, but increased to 127 and $159 \mathrm{~kg} \mathrm{ha}^{-1}$ at the two higher $\mathrm{N}$ rates (Table 6). The data indicate that a large fraction of the apparent $\mathrm{N}$ losses was due to $\mathrm{NO}_{3}-\mathrm{N}$ leaching below $100 \mathrm{~cm}$ depth (accumulated in 100$200 \mathrm{~cm}$ soil layer) while gaseous $\mathrm{N}$ losses (as $\mathrm{NH}_{3}$ volatilization and denitrification) and the $\mathrm{N}$ unaccounted for contributed only marginally to the total $\mathrm{N}$ losses (Table 6).
In the 1999 maize growth season, the apparent $\mathrm{N}$ losses in all three $\mathrm{N}$ treatments (N120, N240 and $\mathrm{N} 360$ ) were much greater than in the previous winter wheat season (Table 6). However, the $\mathrm{NO}_{3}-\mathrm{N}$ leaching $\left(16-38 \mathrm{~kg} \mathrm{ha}^{-1}\right)$ and gaseous $\mathrm{N}$ losses $(12-27 \mathrm{~kg}$ $\mathrm{ha}^{-1}$ ) in all $\mathrm{N}$ treatments were relatively small and comparable in the maize season. The large amounts of $\mathrm{N}$ unaccounted for (Table 6) suggest that a considerable amount of fertilizer $\mathrm{N}$ was immobilized, lost through plant shoots or denitrified in the subsoil in the 1999 maize season.

During the 1999-2000 winter wheat growing season, this large apparent $\mathrm{N}$ loss was observed only in the N360 treatment, indicating that $\mathrm{N}$ leaching losses as $\mathrm{NO}_{3}-\mathrm{N}$ were much higher than in the other treatments (Table 6). Among the total $\mathrm{N}$ losses, $\mathrm{NO}_{3}-\mathrm{N}$ leaching accounted for the main part in the N240 and N360 treatments. Lower N level (N120) led to much lower $\mathrm{N}$ leaching but relatively high $\mathrm{N}$ unaccounted for compared with the higher $\mathrm{N}$ levels.

During the 2000 maize growing season, a gain in $\mathrm{N}$ was measured under all $\mathrm{N}$ treatments. This was because the September 2000 soil $\mathrm{NO}_{3}-\mathrm{N}$ levels were higher than the June 2000 levels due to a large amount of $\mathrm{N}$ mineralized during the summer season. Elevated residual soil $\mathrm{NO}_{3}-\mathrm{N}$ levels were measured down to $300 \mathrm{~cm}$ (Fig. 3 and Table 4) with rates of 240 and $360 \mathrm{~kg} \mathrm{ha}^{-1}$ after harvest of maize in 2000, suggesting that the accumulation of $\mathrm{NO}_{3}-\mathrm{N}$ in the $100-300 \mathrm{~cm}$ layer from $\mathrm{NO}_{3}-\mathrm{N}$ leaching below $100 \mathrm{~cm}$ soil depth was the main pathway for $\mathrm{N}$ losses during this period.

After two cycles of the rotation, the total apparent $\mathrm{N}$ losses were 180, 360 and $691 \mathrm{~kg} \mathrm{ha}^{-1}$ in N120, N240 and N360 treatments while the accumulated $\mathrm{NO}_{3}-\mathrm{N}$ leaching were 120,321 and $510 \mathrm{~kg} \mathrm{ha}^{-1}$ in above three $\mathrm{N}$ treatments, respectively. In contrast, gaseous $\mathrm{N}$ losses were much lower than $\mathrm{N}$ leaching in the corresponding $\mathrm{N}$ treatments especially at the higher $\mathrm{N}$ levels. The close relationship between total apparent $\mathrm{N}$ loss and $\mathrm{NO}_{3}-\mathrm{N}$ leaching further supports the conclusion that $\mathrm{NO}_{3}-\mathrm{N}$ leaching was the main loss pathway in the winter wheat-maize cropping system.

Weier (1994) reviewed the nitrogen loss in agriculture in subtropical Australia. He found that the leaching of added or mineralized $\mathrm{N}$ was the major pathway of $\mathrm{N}$ removal from that used for sorghum production. 
In a 5-year field lysimeter study, Rasse et al. (1999) showed that about $23 \%$ of fertilizer $\mathrm{N}^{2} \mathrm{NO}_{3}-\mathrm{N}$ could be leached out of $1.83 \mathrm{~m}$ soil depth when the $\mathrm{N}$ rates were $202 \mathrm{~kg} \mathrm{~N}^{-1}$ per year while the leaching loss dropped to $17 \%$ at $\mathrm{N}$ rate of $101 \mathrm{~kg} \mathrm{~N} \mathrm{ha}^{-1}$ per year in the inbred maize systems. These results agreed with our findings on the $\mathrm{N}$ loss pathway in the winter wheat-maize rotation.

\section{Conclusions}

Traditional tillage improved $\mathrm{N}$ mineralization and total $\mathrm{N}$ supply and thus masked the effects of $\mathrm{N}$ fertilizer on yields in the first crop of the study. In the subsequent crops, $\mathrm{N}$ levels significantly affected crop yields, $\mathrm{N}$ utilization, soil $\mathrm{NO}_{3}-\mathrm{N}$ accumulation and $\mathrm{N}$ losses. Nitrogen use efficiency rapidly decreased with increasing over-fertilization. The recommended $\mathrm{N}$ rate $\left(120 \mathrm{~kg} \mathrm{~N} \mathrm{ha}^{-1}\right)$ was effective in reducing gaseous and leaching losses of $\mathrm{N}$, minimizing over-fertilization, and maintaining good crop yields compared to the traditional and high $\mathrm{N}$ rates (240 and $360 \mathrm{~kg} \mathrm{~N} \mathrm{ha}^{-1}$ ). Soil $\mathrm{NO}_{3}-\mathrm{N}$ levels increased substantially when $\mathrm{N}$ application rate exceeded crop requirements during the four growing seasons of winter wheat and maize. The dynamics of $\mathrm{NO}_{3}-\mathrm{N}$ in the soil profile showed that high nitrate leaching losses occurred at conventional and high $\mathrm{N}$ application rates. The $\mathrm{N}$ budgets indicated that $\mathrm{N}$ losses via $\mathrm{NH}_{3}$ volatilization and denitrification were comparatively small while $\mathrm{NO}_{3}-\mathrm{N}$ leaching with movement below $100 \mathrm{~cm}$ soil depth was the major pathway for $\mathrm{N}$ losses in the winter wheat-maize cropping system.

In general, minimizing $\mathrm{N}$ leaching losses requires precise estimation of $\mathrm{N}$ fertilizer needs, particularly in high-yielding production systems. The traditional $\mathrm{N}$ rates practiced by farmers on the North China Plain exceeded the crop $\mathrm{N}$ requirement regardless of soil $\mathrm{N}$ supply. A 50\% reduction in fertilizer $\mathrm{N}$ on the basis of conventional $\mathrm{N}$ application $\left(240 \mathrm{~kg} \mathrm{ha}^{-1}\right)$ still maintained high grain yields, improved $\mathrm{N}$ utilization and prevented $\mathrm{NO}_{3}-\mathrm{N}$ accumulation in the soil profile, showing the large potential for saving $\mathrm{N}$ on highly fertile soils. The soil $\mathrm{N}_{\min }$ test (mainly for $\mathrm{NO}_{3}-\mathrm{N}$ ) is likely to be an effective $\mathrm{N}$ recommendation tool for the purpose of precise $\mathrm{N}$ management (Wehrmann and Scharf, 1986). Our previous results (Liu et al., 2003a,b) identified the possibility of the $\mathrm{N}_{\min }$ method for $\mathrm{N}$ management in winter wheat and maize crops in a neighboring site in Beijing. According to those studies, the optimized $\mathrm{N}$ supply (fertilizer $\mathrm{N}$ plus soil $\mathrm{N}_{\text {min }}$ ) was $180 \mathrm{~kg} \mathrm{~N} \mathrm{ha}^{-1}$ for both winter wheat and maize crops. The actual N supply in N120 treatment was even higher than the optimized $\mathrm{N}$ supply by the $\mathrm{N}_{\text {min }}$ method in the present study if both $\mathrm{NO}_{3}-\mathrm{N}$ and $\mathrm{NH}_{4}-\mathrm{N}$ contents were also included, suggesting that the recommended fixed-N rate be further optimized in high-yielding winter wheat-maize cropping systems.

\section{Acknowledgements}

We thank Prof. H. Goldbach (Director of the Institute of Plant Nutrition, University of Bonn, Germany) and two anonymous referees for their valuable comments on the manuscript. We also acknowledge the generous financial support of the Major State Basic Research Development Program of the People's Republic of China (no. 1999011707), the National Natural Scientific Foundation of China (no. 30270787) and the Key Project of the Chinese Ministry of Agriculture (no. 0112).

\section{References}

Anonymous, 2001. China Agricultural Yearbook. Agricultural Publishing House, Beijing, China (in Chinese).

Beyrouty, C.A., Sommers, L.E., Nelson, D.W., 1988. Ammonia volatilization from surface-applied urea as affected by several phosphoroamide compounds. Soil Sci. Soc. Am. J. 52, 1173-1178.

Blankenau, K., Kuhlmann, H., 2000. Effect of $\mathrm{N}$ supply on apparent recovery of fertilizer $\mathrm{N}$ as crop $\mathrm{N}$ and $\mathrm{N}_{\min }$ in soil during and after cultivation of winter cereals. J. Plant Nutr. Soil Sci. 163, 91-100.

Bremner, J.M., 1996. Nitrogen-total. In: Sparks, D.L., Page, A.L., Johnston, C.T., Summer, M.E. (Eds.), Methods of Soil Analysis. Part 3. Chemical Methods. SSSA Book Ser. No. 5. SSSA, Madison, WI, pp. 1085-1121.

Cai, G.X., 1997. Ammonia volatilization. In: Zhu, Z.L., Wen, Q.X., Freney, J.R. (Eds.), Nitrogen in Soils of China. Kluwer Academic Publishers, Dordrecht, pp. 193-213.

Cao, Q.H., 2002. Simulating analysis of nitrogen leaching characteristic as influenced by stochastic rainfall/climatic variation under wheat-corn cropping system. Ph.D. Dissertation. China Agricultural University, Beijing, China (in Chinese with English abstract). 
Chen, X., Zhou, J.Q., Wang, X.R., Zhang, F.S., 2000. A model selection on nitrogen fertilizer effects in wheat-maize rotation system: analysis of economical and environmental profits. Acta Pedol. Sinica 37, 346-354 (in Chinese with English abstract).

Davies, D.B., Sylvester-Bradley, R., 1995. The contribution of fertiliser nitrogen to leachable nitrogen in the UK: a review. J. Sci. Food Agric. 68, 399-406.

Diez, J.A., Roman, R., Caballero, R., Caballero, A., 1997. Nitrate leaching from soils under a corn-wheat-corn sequence, two irrigation schedules and three types of fertilizers. Agric. Ecosyst. Environ. 65, 189-199.

Diez, J.A., Caballero, R., Tarquis, A., Cartagena, M.C., Vallejo, A., 2000. Integrated fertilizer and irrigation management to reduce nitrate leaching in central Spain. J. Environ. Qual. 29, 1539-1547.

Fixen, P.E., West, F.B., 2002. Nitrogen fertilizers: meeting contemporary challenges. Ambio 31, 169-176.

Jarvis, S.C., 1996. Future trends in nitrogen research. Plant Soil $181,47-56$.

Liu, X.H., Mu, Z.G. (Eds.), 1993. Cropping systems in Huanghuaihai region. In: Cropping Systems in China. Agricultural Press of China, Beijing, pp. 388-407 (in Chinese).

Liu, B.C., Sun, M.D., Wu, J., 1999. Soil fertility and fertilization in Beijing area. Beijing Agric. Sci. 17 (6), 30-34 (in Chinese).

Liu, X.J., Ju, X.T., Zhang, F.S., 2001. Effect of urea application as basal fertilizer on inorganic nitrogen in soil profile. J. China Agric. Univ. 7 (5), 63-68 (in Chinese with English abstract).

Liu, X.J., Ju, X.T., Zhang, F.S., Chen, X.P., 2003a. Nitrogen recommendation for winter wheat using $\mathrm{N}_{\text {min }}$ test and rapid plant tests in North China Plain. Commun. Soil Sci. Plant Anal., in press.

Liu, X.J., Ju, X.T., Zhang, F.S., Chen, X.P., Romheld, V., 2003b. Nitrogen recommendation for summer maize using $\mathrm{N}_{\text {min }}$ test and rapid plant tests in northern China. Pedosphere, in press.

Lu, D.Q., Tong, Y.A., Sun, B.H., Emtered, O., 1998. Studies on effect of nitrogen fertilization to environment. Plant Nutr. Fert. Sci. 4, 8-15 (in Chinese with English abstract).

Ma, W.Q., 1999. Current status and evaluation of crop fertilization in Shandong province. Ph.D. Thesis. China Agricultural University, Beijing, China (in Chinese with English abstract).

MacGregor, J.M., Blake, G.R., Evans, S.D., 1974. Mineral nitrogen movement into subsoils following continued annual fertilization for corn. Soil Sci. Soc. Am. Proc. 38, 110-113.

Mosier, A.R., Guenzi, W.D., Schweizer, E.E., 1986. Field denitrification estimation by nitrogen-15 and acetylene inhibition techniques. Soil Sci. Soc. Am. J. 50, 831-833.

Nieder, R., Kersebaum, K.C., Richter, J., 1995. Significance of nitrate leaching and long term $\mathrm{N}$ immobilization after deepening the plough layers for the $\mathrm{N}$ regime of arable soils in northwestern Germany. Plant Soil 173, 167-175.

Nommik, H., 1973. The effect of pellet size on the ammonia loss from urea applied to forest soil. Plant Soil 39, 309-318.

Parker, D.T., Larson, W.E., 1962. Nitrification as affected by temperature and moisture content of mulched soil. Soil Sci. Soc. Am. Proc. 26, 238-242.

Rasse, D.P., Ritchie, J.T., Perterson, W.R., Loudon, T.L., Martin, E.C., 1999. Nitrogen management impacts on yield and nitrate leaching in inbred maize systems. J. Environ. Qual. 28, 1365-1371.
Richter, J., Roelcke, M., 2000. The N-cycle as determined by intensive agriculture-examples from central Europe and China. Nutr. Cycl. Agroecosyst. 57, 33-46.

Ryden, C., Rolston, D.E., 1983. The measurement of denitrification. In: Freney, J.R., Simpson, J.R. (Eds.), Gaseous Loss of Nitrogen From Plant-Soil Systems. Book Series of Developments in Plant and Soil Sciences, vol. 9. Martinus Nijhoff, Dordrecht, pp. 91-132.

Ryden, J.C., Skinner, J.H., Nixon, D.J., 1987. Soil core incubation system for the field measurement of denitrification using acetylene-inhibition. Soil Biol. Biochem. 19, 753-757.

Sanchez, L., Diez, J.A., Vallejo, A., Cartagena, M.C., 2001. Denitrification losses from irrigated crops in central Spain. Soil Biol. Biochem. 33, 1201-1209.

Sapek, A., 1997. Nitrogen balances in permanent grassland. In: Jarvis, S.C., Pain, B.F. (Eds.), Gaseous Nitrogen Emissions from Grasslands. CAB International, London, pp. 391-393.

SAS Institute, 1996. SAS User's Guide. SAS Institute, Cary, NC.

Sogbedji, J.M., van Es, J.M., Yang, C.L., Geohring, L.D., Magdoff, F.R., 2000. Nitrate leaching and nitrogen budget as affected by maize nitrogen rate and soil type. J. Environ. Qual. 29, 1813-1820.

Sommer, S.G., Jensen, C., 1994. Ammonia volatilization from urea and ammoniacal fertilizers surface applied to winter wheat and grassland. Fert. Res. 37, 85-92.

Spalding, R.F., Exner, M.E., 1993. Occurrence of nitrate in groundwater: a review. J. Environ. Qual. 22, 2229-2236.

van der Ploeg, R.R., Ringe, H., Galina, M., Hermsmeyer, D., 1997. Postwar nitrogen use efficiency in West German agriculture and groundwater quality. J. Environ. Qual. 26, 1203-1212.

Wang, Z., Liu, X., Ju, X., Zhang, F., 2002. In situ determination of ammonia volatilization from wheat-maize rotation system field in North China. Acta Ecol. Sinica 22, 359-365 (in Chinese with English abstract).

Wehrmann, J., Scharf, H.C., 1986. The $\mathrm{N}_{\min }$-method: an aid to integrating various objectives of nitrogen fertilization. Z. Pflanzenernaehr. Bodenkd 149, 428-440.

Weier, K.L., 1994. Nitrogen use and losses in agriculture in subtropical Australia. Fert. Res. 39, 245-257.

Westerman, R.L., Boman, R.K., Raun, W.R., Johnson, G.V., 1994. Ammonium and nitrate nitrogen in soil profiles of long-term winter wheat fertilization experiments. Agron. J. 86, 94-99.

Xing, G.X., Zhu, Z.L., 2000. An assessment of $\mathrm{N}$ loss from agricultural fields to the environment in China. Nutr. Cycl. Agroecosyst. 57, 67-73.

Yuan, X.M., 1999. Soil nitrate nitrogen accumulation and its influencing factors in Loess Plateau Area. Ph.D. Thesis. China Agricultural University, Beijing, China (in Chinese with English abstract).

Yuan, F., Chen, Z., Yao, Z., 1995. The transformation, accumulation and leaching loss of surface layer $\mathrm{NO}_{3}-\mathrm{N}$ in a fluvo-aquic soil in Beijing area. Acta Pedol. Sinica 32, 388-399 (in Chinese with English abstract).

Zhang, S.L., Zhu, Z.L., Xu, Y.H., 1989. The transformation of urea and the fate of fertilizer nitrogen in Fluvo-Aquic soil-winter wheat system in flooded plain of Huanghe river. Acta Agric. Nucl. Sinica 3, 9-15 (in Chinese with English abstract). 
Zhang, S.L., Cai, G.X., Wang, X.Z., Xu, Y.H., Zhu, Z.L., Freney, J.R., 1992. Losses of urea-nitrogen applied to maize grown on a calcareous fluvo-aquic soil of North China Plain. Pedosphere 2, 171-178.

Zhang, W.L., Tian, Z.X., Zhang, N., Li, X.Q., 1996. Nitrate pollution of groundwater in northern China. Agric. Ecosyst. Environ. 59, 223-231.

Zhao, J.R., Guo, Q., Guo, J.R., Wei, D.M., Wang, C.W., Liu, Y., Lin, K., 1997. Investigation and analysis on current status of chemical fertilizer inputs and crop yields in agricultural field of Beijing Suburb. J. Beijing Agric. Sci. 15 (2), 36-38 (in Chinese).

Zheng, X.H., Fu, C.B., Xu, X.K., Yan, X.D., Huang, Y., Han, S.H., Hu, F., Chen, G.X., 2002. The Asian nitrogen cycle case study. Ambio 31, 79-87.

Zhou, S.L., Zhang, F.S., Wang, X.R., 2001. Variety differences of winter wheat yield components and $\mathrm{N}$-fertilizer effects in high-yield condition. J. Triticeae Crops 21 (2), 67-71 (in Chinese with English abstract).
Zhu, Z.L., 1997. Nitrogen balance and cycling in agroecosystems of China. In: Zhu, Z.L., Wen, Q.X., Freney, J.R. (Eds.), Nitrogen in Soils of China. Kluwer Academic Publishers, Dordrecht, pp. 323-338.

Zhu, Z.L., 1998. Soil nitrogen fertility and its management in China. In: Shen, S.M. (Ed.), Soil Fertility in China. China Agricultural Publisher, Beijing, pp. 160-211 (in Chinese).

Zhu, Z.L., Chen, D.L., 2002. Nitrogen fertilizer use in Chinacontributions to food production, impacts on the environment and best management strategies. Nutr. Cycl. Agroecosyst. 63, 117-127.

Zhu, Z., Stewart, B.A., Fu, X., 1994. Double cropping wheat and corn in a sub-humid region of China. Field Crops Res. 36, 175-184.

Zou, G., 2001. Nitrification-denitrification of fertilizer nitrogen in winter wheat/summer maize rotation system. Ph.D. Dissertation. China Agricultural University, Beijing, China (in Chinese with English abstract). 